\title{
"Of Me and of Mine": The Music of Racial Identity in Whitman and Lanier, Dvořák and DuBois
}

John Kerkering

Loyola University Chicago, jkerker@luc.edu

Follow this and additional works at: https://ecommons.luc.edu/english_facpubs

Part of the English Language and Literature Commons

\section{Recommended Citation}

Kerkering, John. "Of Me and of Mine": The Music of Racial Identity in Whitman and Lanier, Dvořák and DuBois. American Literature, 73, 1: 147-184, 2001. Retrieved from Loyola eCommons, English: Faculty Publications and Other Works,

This Article is brought to you for free and open access by the Faculty Publications and Other Works by Department at Loyola eCommons. It has been accepted for inclusion in English: Faculty Publications and Other Works by an authorized administrator of Loyola eCommons. For more information, please contact ecommons@luc.edu. c) (i) $\Theta$

This work is licensed under a Creative Commons Attribution-Noncommercial-No Derivative Works 3.0 License. (c) Duke University Press, 2001. 
"Of Me and of Mine”: The Music of Racial Identity in Whitman and Lanier, Dvořák and DuBois

With Reconstruction entering its tenth year in 1875, plans were underway in Philadelphia for a gala event to mark the following year’s national centennial. Opening ceremonies would feature a choral cantata with music by Northerner Dudley Buck and words by Southerner and former Confederate soldier and poet Sidney Lanier. This collaboration between North and South was deliberately meant to symbolize the national unity that Reconstruction had so far failed to restore. ${ }^{1}$ Lanier's poem “The Centennial Meditation of Columbia,” or the Centennial Cantata, asserts national continuity by personifying America as a single entity, the goddess Columbia, whose declaration "I was: I am: and I shall be” asserts a national will to endure. ${ }^{2}$ Lanier was not the only poet, however, to mark the centennial, for Walt Whitman’s 1876 “Preface” also references “the Centennial at Philadelphia,” describing Leaves of Grass as "my contribution and outpouring to celebrate ... the first Centennial of our New World Nationality.”ํㅡㄹ Both Lanier and Whitman, then, seize the centennial moment to look beyond civil war toward national unity.

In doing so, however, each poet provides a different account of the nation’s history. Whitman invokes the Revolution of 1776 to celebrate a "New World Nationality" that coincides with “the Hundred Years' life of the Republic” ( $L G, 751)$. Figuring the Revolution as a national birth, he asserts: “[A]ll the hitherto experience of The States, their first Century, has been but preparation, adolescence-and ... This Union is only now and henceforth (i.e., since the Secession war) to enter on its full Democratic career” ( $L G, 750)$. In contrast to this account of national maturation, Lanier's Columbia announces not progress but stasis. The line "I was: I am: and I shall be” echoes assertions of divine permanence in the Bible’s Old and New Testaments, ${ }^{4}$ and the poem itself supports such permanence by reaching back to a time well before the 
Revolution when “Jamestown” and "Plymouth” first struggled against "Famine” and "War" (“CMC,” 61). Thus Whitman's narrative of maturation - the struggle of American patriots to free themselves from the British and pursue a “Democratic career”-contrasts with Lanier’s narrative of perpetuation, in which British settlers struggle to extend the ways of the Old World into the New.

Bound up with these different narratives of national history are different approaches to poetic form. “[M]y form,” writes Whitman, "has strictly grown from my purports and facts, and is the analogy of them"- that is, free verse is the "analogy" of "a revolutionary age” $(L G, 755)$. For Lanier, the Centennial Cantata's form involves "the short, sharp, vigorous Saxon words [that] broke, rather than fell, from the lips of the chorus" 5 - and these are not "analogies" of the Revolution but relics of a prior civilization: “[T]he author desiring to experiment upon the quality of tone given out by choral voices when enunciating Saxon words, as compared with that from smoother Latin derivatives, wrote his poem almost entirely in the former” (“CC,” 272). Thus, while Whitman's centennial writings link poetic form to America's revolutionary origins (“Out of the Hundred Years just ending . . my Poems too have found genesis” $[L G, 756]$ ), Lanier derives the formal features of his Centennial Cantata from a source that predates both the Revolution and colonization—from the “abrupt vocables” of Anglo-Saxon (“CC,” 273).

By insisting on Anglo-Saxon sounds in the text of his cantata, Lanier redirects the force of the line “I was: I am: and I shall be,” for although spoken by the New World’s goddess Columbia, these are Old World sounds. And it is this focus on sounds, I will argue, that underwrites Lanier’s break from Whitman’s “New World Nationality.” Where Whitman asserts an “Indissoluble Union” ( $L G, 747)$, Lanier’s concern is the sounds of Anglo-Saxon; where Whitman’s poetic form underwrites an American nation, Lanier’s embodies an Anglo-Saxon 
race. This difference between racial and national forms extends beyond these two writers and into the late-century work of Antonín Dvořák and W. E. B. DuBois. Although the 1890s posed different challenges to the integrity of the nation's identity, replacing Reconstruction's problem of overcoming sectional division with the problem of assimilating newly arrived immigrants, Dvořák and DuBois nevertheless consolidate a people by reproducing their predecessors’ reliance on form: Dvořák repeats Whitman’s emphasis on the forms of a New World nation and DuBois follows Lanier's reliance on those of an Old World race-not the Anglo-Saxon but, to use DuBois’s term, the Negro race.

By linking Lanier's and DuBois’s commitments to racial forms, I will demonstrate that their categories of Anglo-Saxon and Negro are structurally identical, each relying on racialized sound. What this similarity suggests is that the commitment to race-specific sound was not just to what Houston Baker has called “African sound” and Eric Sundquist "a sound that is ... PanAfrican”- -but it was also, and initially, to Pan-Anglo-Saxon sound. ${ }^{6}$ Moreover, by questioning the plausibility of such panracial sound, whether Anglo-Saxon or Negro, I will show that relying on form to do the work of racial identity ultimately amounts to an act of arbitrary imposition, one that appropriates literary form to the project of underwriting the racial politics emerging in the postbellum United States. Finally, I will show that this racialist approach to sound substantially alters the cultural significance of poems, shifting the focus from the meanings they convey to the sounds — and thus the races - they embody.

\section{From Words to Music}

Lanier’s interest in Anglo-Saxon sounds stands apart from other prominent discussions of Anglo-Saxon in the United States during the nineteenth century. The centrality of Anglo-Saxon 
to the curriculum at the University of Virginia (1819), for instance, reflected Thomas Jefferson's aim of inculcating solid citizenship in young Americans who, he writes, "will imbibe with the language their free principles of government." ${ }^{\underline{7}}$ By midcentury this educational goal had escalated into Manifest Destiny’s geopolitical mission of imposing Anglo-Saxon institutions on “inferior” non-Americans..$^{8}$ A corollary to this expansionist Anglo-Saxonism was an insular nativist desire to protect New England’s Anglo-Saxon elite from the influx of supposedly “degenerate” immigrants. ${ }^{9}$ In a specifically Southern version of this insularity, one presumably closer to Lanier’s interests, defeated Confederates drew “a cultural analogy that aligned Southerners with Anglo-Saxons and Northerners with the Normans," an analogy that "provided comfort to Southerners who believed their region had been unjustly conquered by antidemocratic forces”; like the Anglo-Saxons before them, they too would preserve and perpetuate their indigenous values, embodied in the Confederate cause. ${ }^{10}$ While this analogy may help explain an upsurge in Anglo-Saxon language instruction in the postwar South, $\frac{11}{2}$ such nostalgia for the Confederacy runs counter not only to ideas Lanier put forth in the Centennial Cantata but also to his other statements of support for sectional reconciliation. Lanier’s interest in Anglo-Saxon sound was driven, then, not by lingering sectionalism but by a desire for national reunification, and he was able to turn it in that direction through his involvement with two emerging academic disciplines.

The first of these disciplines was scientific philology, which Lanier encountered at Johns Hopkins, a research university patterned after the German model and founded in Baltimore in 1876. Having moved to Baltimore in 1873 to play flute in a local orchestra, Lanier petitioned Daniel Coit Gilman, the university’s first president, for an appointment in "Poetry and Music,” 12 and he later proposed a course "suitable to a student of philology who is pursuing Anglo- 
Saxon.”를 ${ }^{13}$ Gilman, however, was seeking a specialist in philology; although Lanier was eventually appointed Lecturer in English in 1879, in the meantime Gilman arranged visiting lectures by William Dwight Whitney, whose The Life and Growth of Language (1875) had set out the general aim of the new school of philologists. ${ }^{14}$ Countering earlier romantic philologists who claimed that "words get themselves attributed to things by a kind of mysterious natural process, in which men have no part," Whitney describes language as made up of "signs which have no ... natural and necessary connection with the conceptions they indicate ... but are ... arbitrary and conventional." ${ }^{15}$ Language is ultimately a human "institution" in which "the community as final tribunal ... decides whether anything shall be language or not” ( $L G L, 280$, 150). This commitment of the new philology to what Kenneth Cmiel calls a "social compact theory of language” figures prominently in Lanier’s “From Bacon to Beethoven,” an essay composed in 1876, the year of Whitney’s lectures in Baltimore. ${ }^{16}$ "A language,” Lanier insists, "is a set of tones segregated from the great mass of musical sounds, and endowed, by agreement, with fixed meanings. The Anglo-Saxons have, for example, practically agreed that if the sound man is uttered, the intellects of all Anglo-Saxon hearers will act in a certain direction, and always in that direction for that sound.” $\stackrel{17}{ }$ Lanier’s phrase "endowed, by agreement” echoes Whitney’s "arbitrary and conventional” signs, demonstrating Lanier’s embrace of the fundamental claims of the new philology.

In embracing these claims, however, Lanier ultimately aims to redirect attention away from scientific philology and toward his own, somewhat different, concern: pure sound. If a language is "a set of tones segregated from the great mass of musical sounds, and endowed, by agreement, with fixed meanings," then "in the case of music," he continues, "no such convention has been made” (“BB,” 276). Musical tones do not start out as meaningful; on the contrary, as 
part of "the great mass of musical sounds," they are "wholly devoid of intellectual signification in themselves” (“BB,” 277), acquiring meanings only when incorporated into the conventions of a given language. The mistake, then, according to Lanier, is to read the effects of this social process - the arbitrary assignment of meanings to sounds-back onto the original reservoir of musical sounds and assume that music itself is meaningful. $\frac{18}{2}$ Thus Lanier urges readers "to abandon immediately the idea that music is a species of language,- - which is not true,- - and to substitute for that the converse idea that language is a species of music” ("BB,” 276); language, then, is music with a difference-with conventional meanings attached. Moreover, although linked arbitrarily to a meaning, tones retain their initial independence from that meaning, and Lanier's aim is to focus attention on this ongoing musical dimension of a language, its status as

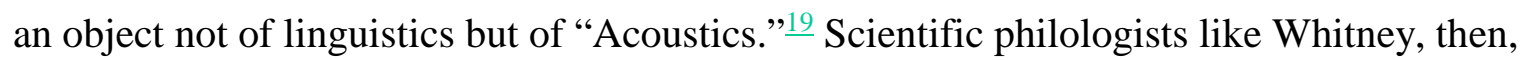
helped Lanier specify how linguists approach language, treating musical tones as arbitrary but meaningful signs, so that he could then set out his own quite separate desire to restore the tones of a language to their status as mere sound. Rescuing language’s “musical sounds” from the procedures of linguistic analysis marks an important first step in Lanier's effort to imagine the Anglo-Saxon sounds of his Centennial Cantata as a basis for sectional reconciliation.

Lanier not only separates a language’s musical status from its semantic function, he also elevates the former over the latter; to do so, he draws from a second academic discipline, the opera theory of Richard Wagner. Wagner’s Beethoven (1870)—which Lanier read and on which he commented ${ }^{20}$ — describes the Ninth Symphony as a “choral cantata” (much like Lanier’s Centennial Cantata) and asserts that "the music bears no relation to the verses other than it would bear to any 'vocal text'”- — that is, the words to Schiller's “Ode to Joy" bear no special or privileged relation to Beethoven’s music. ${ }^{21}$ Thus the words matter to Beethoven's symphony not 
for the message Schiller asks them to convey but for the sounds Beethoven himself uses them to produce. “[I]n truth,” writes Wagner, "it is not the sense of the words that takes hold of us when the human voice enters, but the tone of the human voice itself” ( $B, 70)$. Because Beethoven composes with the tones of human voices as well as those of violins and trumpets, this attention to tone over sense illustrates, for Wagner (and for Lanier), the general principle that "[a] union of music with poetry must . . . always result in . . . a subordination of the latter” $(B, 74) . \underline{22}$ Having praised Beethoven for this innovation, Wagner goes on to compose his remaining operas according to this principle of subordinating libretto to score. $\underline{\underline{23}}$

What Wagner does for opera, Lanier's The Science of English Verse (1880) does for poetry, but while Wagner sees a hierarchy between the libretto and the score that subordinates words to music, Lanier finds it within the poem itself- that is, between its words understood as Whitney’s arbitrary signs and its words understood as Wagner’s musical sounds. Anglo-Saxons may well have "practically agreed that if the sound man is uttered, the intellects of all AngloSaxon hearers will act in a certain direction, and always in that direction for that sound," but this convention is effectively suspended when the sound “man” appears in a poem (“BB,” 276). "In fine,” writes Lanier, “when the term 'words' is used as describing the peculiar set of sounds used in verse, the reader must understand it merely as a convenient method of singling out that specialized set of musical sounds made by the musical instrument called 'the human speakingvoice.” ${ }^{24}$ And for Lanier, “[T]he tones of the human voice are in themselves as meaningless, intellectually, as the tones of all other reed-instruments” (“BB,” 280). In the case of "formal poetry silently perused by the eye of a reader," the words on the page are not semantic symbols but sound-indicators: "[T]he characters of print or writing in which the words are embodied are simply signs of sounds” (SEV, 21). Ultimately, for Lanier, “formal poetry . . impresses itself 
upon the ear as verse only by means of certain relations existing among its component words considered purely as sounds, without reference to their associated ideas.”

By abandoning the philologist's concern with conventional meaning while retaining the medium of musical sound, the writer of poetry thus becomes a composer of music. This 1880 treatise helps clarify Lanier’s 1876 cantata text. Unlike Beethoven’s Ninth Symphony, in which the text of Schiller's “Ode to Joy” is, according to Wagner, subordinate to the music, Lanier’s poem is music; Columbia’s statement “I was: I am: and I shall be,” then, does not produce meaning conventionally, for as a line of poetry, it is just sound, and as sound, it has no meaning. Properly construed, this “meaningless” line tells us nothing at all about the continuity of national identity in the United States; rather, it is just being music. Thus the Centennial Cantata is not the union of a Southerner's text with a Northerner’s music so much as a single, jointly composed musical score; in that sense, it would seem to provide a more potent symbol of postwar reconciliation than a pairing of text and music ever could. Instead of reproducing the distinction between North and South in the difference between text and music, it replaces that distinction with an internally unified national artifact—one medium for one United States.

From Music to Race

To describe the Centennial Cantata as national music, however, is to overlook Lanier's concern with race, which emerges as he distances himself from contemporary debates on proper usage. Whitney, among others, used his philological findings to critique the notion, widely held among verbal critics, that “proper” language was the basis of an ideal cultural ethos. If all conventions of usage are intrinsically arbitrary, Whitney reasons, then no pattern of usage is more proper than another, and thus no speaker can legitimately invoke language practice to claim superior standing. This line of argument leads scientific philologists like Whitney to accept the 
shifting usage and slang so galling to verbal critics, for as Whitney asserts, the ultimate justification of any usage, whether refined or slang, is necessarily circular: “'It was the usage’” (LGL, 141). $\stackrel{25}{ }$ A similar turn from the goal of "proper" usage is evident in Lanier’s 1879 Johns Hopkins lectures, but instead of merely dismissing usage as Whitney does, Lanier replaces the ethos of language users with the ethos of the language itself:

You may have observed that I sometimes speak of the Anglo-Saxon tongue with that peculiar kind of veneration which we accord to a great hero who has fought his way into a lofty position through unspeakable checks and discouragements. English is indeed the Washington of languages; and when you shall have reviewed with me for a moment the astonishing vicissitudes and overwhelming oppressions through which our Anglo-Saxon tongue has managed not only to preserve its idioms but to conquer into its own forms all the alien elements which have often seemed to tyrannize over it, I feel sure your reverence for it will be as great as my own. $\frac{26}{}$

While "reverence" is central here, it is reverence not for users of proper English but for English itself, as a self: by personifying Anglo-Saxon as an entity in its own right, as "the Washington of languages," Lanier makes explicit his impulse in the Centennial Cantata to replace the heroic national figure Columbia with his real hero, “our Anglo-Saxon tongue.” Like Whitney, Lanier has no "reverence" for high usage over low, but unlike Whitney, Lanier does have reverence for persistent identity over assimilation. Thus the ability of Anglo-Saxon "to conquer ... a alien elements" and to incorporate them into its "lofty position" is ultimately a tribute to its ability to "preserve its idioms [and] ... its own forms"-to remain itself. Whitney takes for granted the fact that "[a]ll living language is in a condition of constant growth and change” and seeks a descriptive "classification of the kinds of linguistic change," but Lanier personifies the language 
as an entity struggling to resist such change ( $L G L, 33,36) .{ }^{27}$ While philologists describe and verbal critics prescribe usage, Lanier sets usage aside altogether to focus on the identity inhering in the language itself: despite the changes that Whitney catalogues and verbal critics castigate, the language was, is, and ever shall be.

Lanier does more than praise the language's heroic self-preservation; his lecture also analyzes how it was achieved, addressing what he calls “poetic Form.” 28 While Lanier admits that the language has undergone the very changes Whitney describes in grammar, pronunciation, and semantics, becoming almost unrecognizable to contemporary English speakers, $\underline{\underline{29}}$ in poetic form, Anglo-Saxon remains, as he claims here of Beowulf, the same as it always was: "These words look strange and rugged enough to you at first; but on scanning them attentively, presently you will find one after another putting on a very familiar face and speaking to you with the voice of an old friend." $\underline{30}$ This familiarity stems from a "sense of rhythm which is well-nigh universal in our race," something "founded upon the rhythmic practices of the fathers” (SEV, 113, 146) not founding fathers like Washington but Anglo-Saxon poets of a thousand years ago. Thus while Thomas Jefferson's Anglo-Saxonism focuses on the legal codes of tribal chiefs (leading him to propose two such chiefs, Hengist and Horsa, as central figures on the great seal of the United States), $\frac{31}{2}$ Lanier's Anglo-Saxonism subordinates codes of conduct to scansion of poetic form, inspiring him to prepare two editions of ancient poetry to introduce children to Anglo-

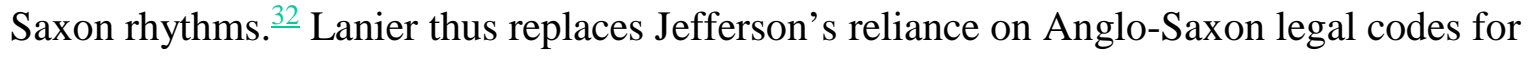
instilling national character with a pattern of sound for perpetuating Anglo-Saxon racial identity.

Lanier's The Science of English Verse gets more specific about racial sounds when it identifies the formal features constituting the persistence of the Anglo-Saxon race over time: "From the beginning of English poetry ... through all the wonderful list down to the present day, 
every long poem and nearly every important short poem in the English language has been written in some form of 3-rhythm” (SEV, 110). Focusing on an example from the tenth century (see fig. 1), Lanier proceeds "to arrange twenty-five lines . .. so that the general reader though wholly unacquainted with Anglo-Saxon may represent to himself with tolerable accuracy the swing and lilt of the original sounds." Setting the words beneath musical staves, with each staff containing the three primary beats of his “3-rhythm," he provides “directions” for “pronunciation” (SEV, 114). What results is a "musical map" for reproducing, even in the absence of comprehension, "the mighty rhythm which beats through all these songs" (SEV, 118, 112). Commenting on the result, he concludes: “[I]n truth I do not know where to look in English poetry, old or new, for a succession of words which make more manly music as mere sounds” (SEV, 119)..$^{\underline{33}}$

Not only older poems display this race-specific sound; Lanier also finds "the most modern English verse tending into the very specific forms of 3-rhythm used by our earliest ancestral poets” (SEV, 137). Lanier describes Tennyson, his contemporary, as having “carried-on the ancient battle-rhythmus of the fathers," which "never varies from the beginning to the end of what we may call Anglo-Saxon poetry” (SEV, 142, 120). This continuity likewise applies to Lanier’s own work. Having composed his Centennial Cantata in the precise forms-the “abrupt vocables" —of these Anglo-Saxon fathers, his line "I was: I am: and I shall be” is not only, as we saw before, simply being music (rather than being about the United States), it is also being Anglo-Saxon. Lanier, it would seem, is less an American than an Anglo-Saxon poet, and his Centennial Cantata is less a centennial celebration of the nation than a millennial celebration of what he calls “our race” (SEV,113).

Yet if words, as poetry, cease to mean and thus become pure sounds, why should the designation Anglo-Saxon still apply? If a poem's sound is just sound, with no institution of 
meanings behind it, then there is nothing necessarily Anglo-Saxon about it. Lanier himself effectively acknowledges this point when he suggests "the simple experiment of substituting for the words of a formal poem any other words which preserve the accentuation, alliteration, and rhyme, but which convey no ideas to the mind,- - words of some foreign language not understood by the experimenter being the most effective for this purpose. Upon repeating aloud the poem thus treated," he says, "it will be found that the verse-structure has not been impaired” (SEV, 21). If the verse-structure remains intact, then the poem, which is nothing more than this versestructure, remains itself. The words of a language like Anglo-Saxon are thus sufficient but not necessary to produce these sounds. But why, after separating these sounds from a given language's conventional codes, retain that language’s name? If the label Anglo-Saxon serves to specify the institutionalized codes or conventions needed to decipher meanings but no meanings are present — if poems are music, not language — then why make reference to such codes? $?^{34}$

Yet it is precisely Lanier's assimilation of poetry to music that enables a poem’s AngloSaxon identity. Standing aloof from changing conventions, a rhythmic pattern arbitrarily designated as the embodiment of a language's identity allows that language to appear to be one self-like "the Washington of languages.” For Lanier, the heterogeneity of conventions is overcome by the continuity of sound, which is more than mere sound in its also being AngloSaxon sound. As such, it remains itself across time, from the tenth century through Tennyson. For Lanier, the arbitrariness of casting these forms as essentially racial presents no obstacle; race inheres in the formal features of archaic poetry, and the superintendents of racial continuity are people like himself, literary scholars empowered by their critical procedures to discern the racial identity intrinsic to a line. Poems become a repository for metrical effects that lie ready to be disclosed by formal analysis so that they can do the work of embodying the persistence of a race. 
While Lanier's application of musical notation to the study of poems has made only a marginal impact on prosody, $\frac{35}{5}$ of far greater significance, we will see, has been this idea of reducing poems to racial music in order to assert the persistence of a race's identity. $\underline{36}$

\section{Lanier’s Anglo-Saxon Whitman}

Lanier's reduction of poems to music encounters the opposite claim in Whitman's "Eidólons," a poem first published in 1876 and collected in that year's edition of Leaves of Grass. The poem's speaker meets a "seer" who encourages him to "Put in thy chants ... / . . eidólons,” which "Ever shall be, ever have been and are” $(L G, 5,7)$. Whitman’s line virtually repeats Lanier’s “I was: I am: and I shall be,” but while Lanier’s line consists not of words but sounds (sounds that do not refer but, rather, embody "the ancient battle-rhythmus of the fathers”), Whitman's line contains words that merely mean, describing without also embodying "[t]he entities of entities, eidólons" $(L G, 7)$. Thus Whitman separates the poem itself from the eidólon, and his commitment to doing so stems from the poem's more general adherence to a Swedenborgian doctrine of correspondences. ${ }^{37}$ That is, the poem aligns all physical objects with privileged metaphysical counterparts ("The true realities" [LG, 7]), as in the following correlation of the physical body with its more "permanent” eidólon:

Thy body permanent, The body lurking there within thy body, The only purport of the form thou art, the real I myself, An image, an eidólon. $(L G, 8)$

By establishing a correspondence between the "body" and the "body permanent," the poem precludes a conflation of the two entities: "Thy very songs not in thy songs" $(L G, 8)$. But if the poem cannot be its own eidólon, its “very song," it can at least be about such eidólons, and this is precisely the seer’s advice. To "Put in thy chants ... / . . eidólons" is to make poems that sing 
"No more the puzzling hour nor day, nor segments, parts" but that, instead, sing about "The whole .. . summ’d, added up, / In its eidólon” $(L G, 5,6)$. To embrace the seer’s advice, however, is to turn from Lanier’s practice. For Whitman's speaker, poems are words instead of music, so they merely represent instead of embodying the eidólons that "Ever shall be, ever have been and are”; instead of embodying permanence (as does Lanier’s line), they merely report it.

If Whitman differs from Lanier in distinguishing between the "very song” and the poem, he resembles him in equating these very songs with the identity of a people-not Anglo-Saxons but Americans. Just as material objects have eidólons, so do nations, and as the United States emerges materially as a nation, it releases corresponding national eidólons:

The present now and here, America's busy, teeming, intricate whirl, Of aggregate and segregate for only thence releasing, To-day’s eidólons. $(L G, 6)$

In the 1876 “Preface” to Leaves of Grass, Whitman quotes from “Eidólons” to specify the general project of all his poems: "The Prophet and the Bard / . . . Shall mediate to the Modern, to Democracy-interpret yet to them, / God and Eidólons” (LG, 755). Himself such a "Bard,” Whitman writes poems that, as a group, seek to "mediate” the relation between Americans and the eidólons they release, helping them look past their selves to see their very selves: “I . . now bequeath Poems and Essays as nutriment and influences . . . to furnish something toward what The States most need of all, .. . namely, to show them, or begin to show them, Themselves distinctively" ( $L G, 754)$. This ambition to "show” Americans their very selves makes Whitman the kind of poet the seer suggests, a witness ("as I have lived in fresh lands . . . in a revolutionary age, ... I have felt to identify the points of that age" $[L G, 755])$ whose poems testify to the enduring significance of the United States as a nation. Thus while Lanier features poems that embody (and indeed perpetuate by embodying) the sounds of the Anglo-Saxon past, Whitman 
searches for poems that "show" the eidólons produced in an unfolding American present; thus, Lanier's and Whitman's poetry opposes racial embodiment in a poem's musical sound to national representation via a poem's mediating words.

Whitman’s 1876 "Preface” describes his poems as “my recitatives” $(L G, 755)$ in reference to the inspiration he drew from the opera ("But for the opera I could never have written Leaves of Grass" ${ }^{38}$ ), but his model was the libretto rather than the score, and in his 1881 essay “The Poetry of the Future” Whitman explicitly criticizes contemporary poetry’s excessive focus on sound. ${ }^{39}$ Assessing “our New World [End Page 159] Progress," Whitman laments that "the prevailing flow of poetry ... is (like the music) an expression of mere surface melody,” which, while "perfectly satisfying to the demands of the ear," nevertheless "shrinks with aversion from the sturdy, the universal, the democratic” ( $P W, 2: 490,481)$. Mere surface melody fails to mediate these New World "eidólons," and like Lanier, Whitman associates this melodic impulse with a "current leading literary illustrator of Great Britain” ( $P W, 2: 485,478)$ —Tennyson— whose "verbal melody" shows him to be a "feudalistic" "attaché of the throne" (PW, 2:477, 479, 477). What Whitman seeks, instead, is the work of "future poets ... referring not to a special class, but to the entire people," the people of "the great radical Republic with its ... loud, illpitch'd voice, utterly regardless whether the verb agrees with the nominative” $(P W, 2: 486,478)$. This embrace of improper grammar not only invokes contemporary debates about proper usage (that is, the distinction between the proper language use of a "special class" and the improper language use of the "entire people"), it also superimposes on that distinction a further distinction between two nations, between the English (who speak properly) and the Americans (who do not). ${ }^{40}$ Calling for writing that Tennyson "cannot stomach,” Whitman hopes to encourage an 
“autochthonous national poetry,” “a national poetry which was not English but American” (PW, 2:478, 484, 481).

In a rebuttal explicitly targeted at this essay, Lanier equates Whitman’s call for a “loud, ill-pitch'd voice” with the "crye” of an enemy attacking "English warriors": "And so the Poetry of the Future has advanced upon us . . . , relying upon its loud, ill-pitched voice.” 41 In response to this assault, Lanier alters Whitman’s terms: no longer a matter of improper American usage attacking proper English usage (a question of national difference), he sees in this confrontation Anglo-Saxon forms perpetuating themselves (a question of racial identity). Thus although Whitman "shouts ... of a progress that claims to be winning freedom by substituting formlessness for form,” Anglo-Saxon—“the Washington of languages”-nevertheless retains its essential forms: "Perhaps we may fairly say, gentlemen, it is five hundred years too late to attempt to capture Englishmen with a yell,” for Whitman’s strategy “never yet succeeded as against Anglo-Saxon people.”는 It is not that proper usage defeats improper usage (one nation defeats another) but that form preserves itself against formlessness (racial form remains itself, preserves its identity).

Indeed, this victory of formal persistence is not so much in spite of Whitman but because of him, for according to Lanier, Whitman—despite his effort to write in an English that embraces improper American usage_-writes unwittingly in the rhythmic forms of Anglo-Saxon. To demonstrate, Lanier compares "Song of Myself” to the Anglo-Saxon poem in fig. 1 (see the final line), setting lines of each side-by-side in order to show

that even the form of Whitman's poetry is not poetry of the future but tends constantly into the rhythm of

Brimmanna boda abeod eft ongean, which is the earliest rhythm of our poetry. . . . For example:

I loaf and invite my soul;

I lean and loaf at my ease, observing a spear of summer grass. 
I doat on myself-there is that lot of me and all so luscious. ("LII," 54-55)

What Lanier finds in Whitman’s lines are not brash claims but Anglo-Saxon forms, and he suggests that Whitman's best results come when he quits trying to pass as an American poet and instead embraces his poetry’s essential Anglo-Saxonness: “[O]n the occasion when Whitman has abandoned his theory of formlessness and written in form he has made My Captain, $O$ My Captain [sic] surely one of the most tender and beautiful poems in any language” (LII, 39). ${ }^{43}$ Whitman claimed that his poems were written for Americans in order "to show them ... Themselves distinctively,” but Lanier's formal analysis is indifferent to showing and concerned instead with being, so he recasts revolutionary "formlessness" as persistent Anglo-Saxon sound. Properly construed, the American national poet is in fact-just like Tennyson-a poet of the Anglo-Saxon race. $\frac{44}{4}$

The Racial Alternative to Union

I emphasize these differences in the poetics of Whitman and Lanier to suggest that what is at stake in their disagreement is what one might describe as the emergence of a distinctly racialist poetics. Whitman could insist on the difference between patterns of usage in America and Great Britain because he thought differences in usage were consistent with differences in nationality. Lanier, however, equates the American and English languages, insisting both are Anglo-Saxon, because he considers their national differences entirely compatible with their racial identity; that is, he treats the difference between Great Britain and the United States (the difference between two nations and their conventions of usage) as separate from and subordinate to the continuity of Anglo-Saxon form. Indeed, for Lanier, differences in usage between two nations are as easily overcome as those between two periods in history-all are unified by the ongoing presence of racial rhythm. Lanier extends this Anglo-Saxon identity across national 
boundaries when he claims to find examples of pure Anglo-Saxon pronunciation not only among Americans - thus, "many words in Chaucer [are] spelled exactly as they are pronounced by a Georgia 'cracker' at this day” 45 _ but also among Scotsmen: “[T]he Scotch dialect to the present day ... presents us with many interesting old Anglo-Saxon words in the very forms used by our forefathers.” $\stackrel{46}{ }$ For Lanier, the Scots are, from the perspective of race, as Anglo-Saxon as the Americans.

This racialist poetics helps Lanier solve a problem he had posed in an earlier poem, “Civil Rights” (1874). Written in opposition to the Civil Rights Bill of 1874, this poem registers Lanier’s more general disappointment with the legal measures through which Reconstruction sought to reunite the nation. ${ }^{47}$ It features a Southern speaker who, while conceding that "My way was clear to like 'em [the Yankees], and to treat 'em brotherlee," then complains about the racial equality imposed by "this Civil Rights":

"Them Yanks had throwed us overboard from off the Ship of State. Yes, throwed us both—-both black and white-into the ragin' sea, With but one rotten plank to hold; while they, all safe and free, Stands on the deck, and rams their hands into their pockets tight, And laughs to see we both must drown, or live by makin' fight!

For, Jeems, what in this mortal world of trouble kin be done?

They've made this Southern plank so rotten, it will not bear but one! $\ldots \ldots \ldots \ldots$

By God! ef they don't fling a rope, I'll push the nigger in!” (PPO, 41-42)

The problem, according to this speaker, is that Northern-backed legislation like the Civil Rights Bill places Southern whites, many of whom were already denied civil status because of their

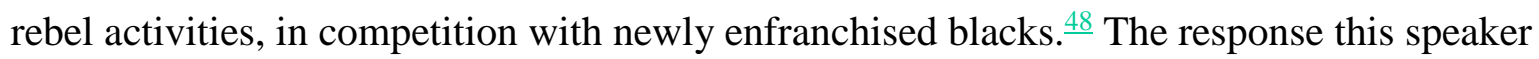
envisions, to "push the nigger in," both offensively and succinctly captures the contemporary politics that Eric Foner describes: while the late 1860s saw a "New Departure” in which Southern "Democrats ... proclaimed their realism and moderation and promised to ease racial 
tensions," the period after the 1873 depression saw a change as "Democrats throughout the South were abandoning the centrist rhetoric of the New Departure in favor of a return to the open racism of early Reconstruction” $(R, 412,547)$. Assisted by Klan violence, this change ultimately led to a widespread sense of "Redemption” for whites, and their return to an exclusive hold on power. ${ }^{49}$ More than merely a Southern policy, Redemption enjoyed the tacit support of Northern whites as well, for as Foner notes, by 1875, "Northern support for Reconstruction was on the wane” and "Congressional Republicans had little stomach for further intervention in Southern affairs” $(R, 544,556)$. They thus permitted a return to "home rule” $(R, 581)$, the 1877 HayesTilden compromise reflecting implicit acceptance of the Redeemers’ white supremacist programs. $\frac{50}{}$ As the Nation remarked after the withdrawal of federal troops in 1877, “The negro will disappear from the field of national politics. Henceforth, the nation, as a nation, will have nothing more to do with him.” $\underline{51}$ Lanier's speaker proves prophetic: it is now blacks, and no longer Southern whites, who would be thrown overboard from the ship of state, and the remaining Northerners and Southerners would now stand together as whites-no longer as regional antagonists but as racial partners. Taking the initiative upon themselves, Southern whites like Lanier would "fling a rope" to Northern whites and replace the regional conflict of Reconstruction with the supposed racial unity of Redemption.

Lanier’s “Civil Rights” anticipates Redemption not only thematically, in the proposal to "push the nigger in,” but also formally, in its being "written in the dialect of the Georgia

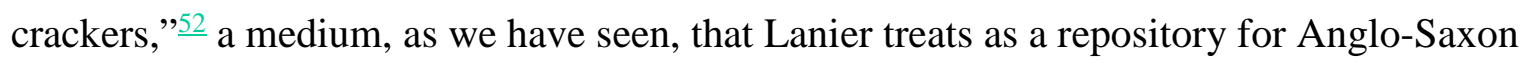
sounds. Thus, when viewed from the perspective of Lanier's later racialist poetics, this poem's form solves the problem raised by its theme: its Anglo-Saxon sounds already embody the shared racial whiteness that would provide the basis of Redemption. Viewed in this way, "Civil Rights" 
anticipates the racial commitments of the following year's Centennial Cantata text. The chief difference between the two poems, then, is not formal (since both have Anglo-Saxon sounds) but thematic: the Centennial Cantata replaces the threat of resistance that “Civil Rights” presents to Northern legislation (“I'll push the nigger in!”) with its own commitment to Anglo-Saxon racial identity (“I was: I am: and I shall be”). Placing the North’s “Plymouth” in apposition—and not opposition- to the South’s “Jamestown,” the Centennial Cantata gives each region a link to white colonial settlement while making no mention of the slave trade or the middle passage. By ignoring the connections of blacks to the Old World (of Africa, not Europe) and emphasizing instead each section's shared tie to Old World Anglo-Saxonism, Lanier directs the nation toward his own vision of postwar unity. We see, then, the political implications of Lanier's poetic break with Whitman: by emphasizing continuity with Britain over Whitman’s New World Nationality, Lanier’s Centennial Cantata does not so much restore the legal Union as it imposes a racial alternative to Union, and the celebration that results features a unity and continuity that are ultimately more racial than national.

Dvořák's American Music

Lanier’s exclusion of African Americans from the American centennial exemplifies the kind of treatment the Fisk Jubilee Singers frequently endured. Although the group "sang the

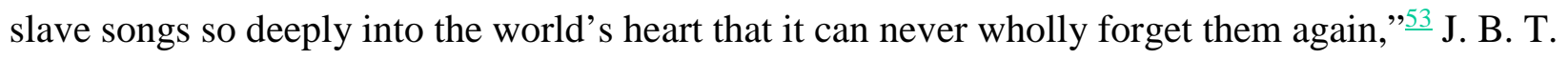
Marsh’s history of the Fisk Jubilee Singers registers the “odious and cruel caste-spirit” that confronted the group during its 1870 performances. But Marsh goes on to emphasize that the group’s music did much to "break down” such “prejudice against color” and to promote, instead, the cause of "social equality." ${ }^{54}$ An 1872 concert in Boston, for instance, "was worth more than a Congressional enactment in bringing that audience to the true ground on the question of 'civil 
rights"” (SJS, 42). This openness proved even greater when the tour left the United States for Britain: at the same time that Lanier was writing the "cracker" dialect of his poem "Civil Rights,” the Jubilee Singers were receiving special reception in Scotland (SJS, 62), and soon after, while Lanier was proposing Anglo-Saxon sounds as the basis of his Centennial Cantata, “the great Christian heart of England gave [the Jubilee Singers] a specially fraternal greeting” (SJS, 82). “After three months in London,” observes one historian, "they invaded and conquered the rest of the British Isles." ${ }^{55}$ Capturing Englishmen with a song, their performance succeeded where, according to Lanier, Whitman’s “loud, ill-pitched voice” could not. $\underline{56}$

The Jubilee Singers did not limit themselves to conquering the seat of Lanier's AngloSaxon language, for their success led them to ask the same question about their songs that Lanier had raised about poems: "Would the slave songs keep their power where the words lost their meaning?” The "where” in question was “on the Continent," and the answer proved to be a resounding yes (SJS, 86). As in England, where "that earnest, evangelistic element in the churches ... prized their services of song as an effective ally in gospel effort,” so too in Germany "the same class of Christian people ... met them with the same fraternal heartiness, and rejoiced in this unique instrumentality for bringing gospel truth to the formalists and the materialists whom it was so difficult to reach" (SJS, 96). Thus the songs are an "instrumentality" for producing a "Christian people," one that is "the same” despite differences in language, nationality, and race-a people, in other words, that is neither racial nor national but ecumenical. $\frac{57}{}$ Encouraged by their international success, the Jubilee Singers “decided to circumnavigate the globe,” making stops in Australia, Japan, and India. While in India they sang at the Taj-Mahal, where “the tones of that beautiful slave song, 'Steal Away to Jesus,' ... awoke the stillness of that most wonderful of temples” (SJS, 124, 146). By singing at the Taj-Mahal 
they effectively accomplished their own version of the passage to India confidently predicted in Whitman’s poetry, for by establishing “the spiritual as a worldwide phenomenon,” $\underline{58}$ their songs became the "international poems” that Whitman had called for in "The Poetry of the Future.” $\underline{59}$ In 1890, "having made the circuit of the globe,” the Jubilee Singers returned to America to find, as the group’s leader put it, that they were “no longer free from that prejudice ... which we had not met with in any other quarter of the globe” (SJS, 152-53). What distinguishes the United States from other nations of the world is its persistent racial prejudice toward African Americans, even despite the achievements of the Jubilee Singers. The notion that the slave songs serve as a reproach to American nationality stands diametrically opposed to the claim Antonín Dvořák would make about them: “It is my opinion,” he wrote the New York Herald in May 1893, “that I find a sure foundation in the Negro melodies for a new national school of music . . . in America.” $\underline{\underline{60}}$ Instead of belonging anywhere but America, as the leader of the Jubilee Singers had suggested, the “Negro melodies,” Dvořák claims, belong to America exclusively. To Dvořák, they are a unique instrumentality for bringing not gospel truth but national identity; the same songs whose international appeal had enabled the Jubilee Singers to overcome national difference serve Dvořák as a “foundation ... for” it. For Dvořák, the songs are not ecumenical but national, consolidating not a Christian but an American people.

The question of American national identity became a matter of concern for Dvořák after he assumed the directorship of New York’s National Conservatory of Music in September 1892. Immediately after his arrival he found himself drawn into ongoing debates about the prospect of an American national music. "I did not come to America to interpret Beethoven or Wagner for the public,” he asserts. “This is not my work and I would not waste any time on it. I came to discover what young Americans had in them and to help them to express it.” $\underline{\underline{1}}$ As this search 
unfolded, however, Dvořák discovered that Americans themselves were increasingly unsure about how to describe their nationality, given the ever expanding influx of foreign immigrants, and, in particular, the so-called “new immigration” from southern and eastern Europe. $\frac{62}{\text { Dvořák's }}$ experience in New York led him to recognize the perspective of those who would argue against an American national music: "Because the population of the United States is composed of many different races ... and because ... the music of all the world is quickly absorbed in this country, they argue that nothing specially original or national can come forth.” ${ }^{63}$ But while Dvorrák acknowledges this account of a hopelessly heterogeneous nation, he nevertheless continues to search for a music that will give it unity:

All races have their distinctively national songs, which they at once recognize as their own, even if they have never hea[r]d them before. When a Tcech, a Pole, or a Magyar in this country suddenly hears one of his folk-songs or dances, no matter if it is for the first time in his life, his eyes light up at once, and his heart within him responds, and claims that music as his own. So it is with those of Teutonic or Celtic blood. ... It is a proper question to ask, what songs, then, belong to the American and appeal more strongly to him than any others? What melody could stop him on the street if he were in a strange land and make the home feeling well up within him? (DA, 376)

As potential sources for this American music, Dvořák lists “the songs of the creoles, the red man’s chant, or the plaintive ditties of the homesick German or Norwegian,” but “according to my estimation," he concludes, the "most potent as well as the most beautiful among them . . . are certain of the so-called plantation melodies and slave songs” (DA, 377), the same music he had singled out early in his visit. Dvorrák associates these songs not with Africa but with the Negro in the South, ${ }^{64}$ and he casts them as the music of all Americans, regardless of race or 
region: "These beautiful and varied themes are the product of the soil. They are American. ... The American musician understands these tunes and they move sentiment in him.” $\underline{65}$ This sentiment is not racial (as with Lanier’s “veneration” for the tones of the Anglo-Saxon tongue) or ecumenical (as with the “Christian song” of the Jubilee Singers) but national: "To read the right meaning the composer need not necessarily be of the same blood,” Dvořák asserts, since “white composers" can write "touching Negro songs" that show a "sympathetic comprehension of the deep pathos of slave life.” ${ }^{66}$ Dvořák himself undertook such an effort in his symphonic arrangement of the spiritual “Old Folks at Home,” and he described the resulting work as "purely national." $\underline{67}$

Dvořák, then, envisions an America like Whitman’s, a New World nation distinct from its European antecedents. Just as Whitman’s poems advocate a “New World Nationality,” so Dvořák has a similar ambition in his symphony From the New World: "My new symphony is ... an endeavor to portray characteristics, such as are distinctly American.”토 sought exposure to Negro melodies by asking Henry Burleigh, an African American student at the National Conservatory, to sing spirituals for him. “It was my privilege,” Burleigh wrote, “to sing repeatedly some of the old plantation songs for him at his house, and one in particular, 'Swing Low, Sweet Chariot,' greatly pleased him, and part of this old spiritual will be found in the second theme of the first movement of the [symphony From the New World], first given out by the flute." $\underline{69}$

The flute was Lanier’s instrument—he played first chair in Baltimore’s Peabody Orchestra-and had he not suffered an early death at age 39, the Baltimore premiere of Dvořák's symphony would no doubt have featured him on this solo. The scenario, although hypothetical, is worth considering: Lanier, a former Confederate soldier and ardent Anglo-Saxon, performing 
a Negro spiritual in Dvořák's all-American symphony. Lanier had turned to music to identify an Anglo-Saxon race, an alternative to Reconstruction's ongoing conflict between sections, but the hypothetical idea of his playing the "Swing Low” melody suggests that Dvořák's music produces an entirely different kind of identity, one that rises above the friction Lanier experienced between North and South and blacks and whites, or the conflict Dvořák observed between immigrants and natives. Dvořák's effort to transform cultural heterogeneity into U.S. nationality aligns his project with Whitman’s: both turn to songs—whether Whitman’s recitatives or Dvořák's melodies—-to establish a national people in the United States.

In describing these musical forms as national, Dvořák diverges from the description in the book distributed by the Jubilee Singers during their tours. That book’s "Preface to the Music" casts the songs as resistant to national designations, like the international audience of the touring singers:

It is a coincidence worthy of note that more than half the melodies . . . are in the same scale as that in which Scottish music is written; that is, with the fourth and seventh tones omitted. The fact that the music of the ancient Greeks is also said to have been written in this scale suggests an interesting inquiry as to whether it may not be a peculiar language of nature, or a simpler alphabet than the ordinary diatonic scale, in which the uncultivated mind finds its easiest expression. $\frac{70}{}$

Here the songs Dvořák built into his symphony From the New World are the "peculiar language of nature,” not of a nation — the mark of a primitive human, not a specific national, culture. In one sense Dvořák agreed, for in a newspaper interview he concedes the formal identity between the plantation melodies and the music of other nations: "I found that the music of the Negroes and of the Indians was practically identical," 71 adding that "the music of the two 
races bore a remarkable similarity to the music of Scotland” (DA, 362): “[T]he Scotch scale, if I may so call it, has been used to impart a certain color to musical composition. . . . The device is a common one" — so common, he continues, that many composers have used it, including Mendelssohn, David, Verdi, and Dvořák himself. "In fact,” he notes, “the scale in question is only a certain form of the ancient ecclesiastical modes" that "have been employed time and time again” (DA, 363) — a mode so common that musicologists continue to discuss it, labeling it Dorian, ${ }^{72}$ which is itself, according to Webster's Tenth, the name of “an ancient Hellenic race.”

To Dvořák, these plantation songs are as plausibly Scottish or Greek as they are Negro or Indian, yet acknowledging this point in no way diminishes his conviction that they are the basis for a music that is distinctively American. This problem of classification raises the same question about Dvořák's symphony that I asked about Lanier’s Anglo-Saxon poem: as musical sounds devoid of conventional meanings, on what grounds should these expressive works bear the name of a specific social group? These sounds may be found in these cultures, but if these cultures impose none of their conventional meanings upon them, are these cultures—Scottish, Negro, U.S., Greek-in these sounds? ${ }^{73}$

A contemporary music critic, James Huneker, raises this very question in his review of Dvořák's From the New World. Turning to the first movement's second theme (the version of “Swing Low Sweet Chariot” played by the flute), he describes it as “negro or oriental, just as you

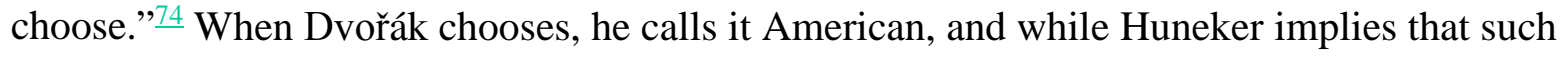
choices are purely arbitrary, Dvořák, openly acknowledging the formal identity among these scales, nevertheless insists that his designation is the right one. Lanier had taken the same approach to the "3-rhythm” of poems, insisting that it was intrinsically Anglo-Saxon. And just as sound's embodiment of a culture was an opportunity for Lanier, helping him unify the 
heterogeneity of Anglo-Saxon across time, so too it was an opportunity for Dvořák, a means for unifying the people of the United States despite an accelerating influx of diverse immigrant groups.

\section{DuBois’s African Music}

The orchestras Dvořák conducted figure prominently in another work from this period, W. E. B. DuBois’s The Souls of Black Folk (1903). In chapter 13, “Of the Coming of John,” John attends a New York performance of Wagner's Lohengrin; as the orchestra plays he begins “to rise with that clear music out of the dirt and dust of that low life that held him prisoned and befouled” (SBF, 193). But no sooner has John’s reverie begun than it is cut short. John’s boyhood playmate, a white man, is also in the audience and is uncomfortable with John's presence; he requests that the color line be enforced, so the opera house and its liberating music are suddenly off limits to John. It was in 1895, the year of Dvořák's return to Prague, that the color line received its infamous sanction from Booker T. Washington: "In all things that are purely social we can be as separate as the fingers, yet one as the hand in all things essential to mutual progress." $\underline{75}$ For John, this separation affects him as much in Georgia as it had in New York, and the cumulative insult drives him to kill his boyhood playmate. Lingering by the body, he once again hears Wagner's music, his memory of it blending with the sound of an approaching lynch mob: "Hark! was it music, or the hurry and shouting of men? Yes, surely! Clear and high the faint sweet melody rose and fluttered like a living thing, so that the very earth trembled as with the tramp of horses and murmur of angry men” $(S B F, 202)$. Wagner's white swan becomes indistinguishable from the "white-haired man” with his "coiling twisted rope" (SBF, 203). John had initially treated Wagner's music as a symbol of escape from the South and 
the color line—as a way to "dwell above the veil” (SBF, 90)—but here the music ultimately merges with the white oppressors and becomes, effectively, white. $\frac{76}{}$

In his next chapter, DuBois explicitly contrasts "the songs of white America" with what Dvořák calls "plantation melodies” and DuBois himself "the Sorrow Songs” (SBF, 209, 204). Dvořák had predicted that Americans would embrace the Negro spirituals as their "distinctively national songs, which they [would] at once recognize as their own, even if they had never hea[r]d them before.” DuBois attributes to the Sorrow Songs the same autochthonous power: “[T]hese songs .... came out of the South unknown to me, one by one, and yet at once I knew them as of me and of mine" (SBF, 204). But there is an important difference in the positions of DuBois and Dvořák, for while Dvořák imagines as “American” the person who “claims that music as his own,” DuBois's description of the Sorrow Songs as “of me and of mine” is meant to cast the listener not as an American among Americans but a Negro among Negroes. This is "primitive African music," he writes, "the voice of exile” in "the foster land” (SBF, 208, 209). Thus DuBois’s turn to the Sorrow Songs looks less like Dvořák's search for American national identity and more like Lanier's assertion of Anglo-Saxon racial continuity. DuBois, in other words, treats these songs not as an alternative to racial distinctions but, like Lanier's Anglo-Saxon rhythm, as a basis for making them. ${ }^{77}$ If DuBois’s Sorrow Songs are "of me and of mine,” then others' songs—“the songs of white America” (SBF, 209)—must be of them and of theirs.

What DuBois might have called white Sorrow Songs can be found in Lanier's The Science of English Verse. Here Lanier quotes a thousand-year-old Anglo-Saxon poem, "calling attention to a profound mournfulness and gentle dignity which breathe subtly out of the melodious movement of the verse. ... Even those who understand no word of Anglo-Saxon must be deeply impressed with the tender sing [sic] which goes all along through the poem, when it is 
properly read aloud” (SEV, 123). DuBois offers a remarkably similar account of the Negro Sorrow Songs: “My grandfather’s grandmother was seized by an evil Dutch trader two centuries ago; and . . . she . . . often crooned a heathen melody [that] ... we sing . . . to our children, knowing as little as our fathers what its words may mean, but knowing well the meaning of its music” (SBF, 207). Although “[w]ords and music have lost each other,” DuBois nonetheless knows that "these songs are the articulate message of the slave to the world" (SBF, 209, 207); loss of meanings, then, does not compromise the standing of the songs as the embodiment of a race. Agreeing with Lanier that words can be separated from music, DuBois also agrees that these extralinguistic sounds are tied to a particular people. Just as DuBois offers a catalog of the Sorrow Songs, singling out "Ten master songs ..._-songs of undoubted Negro origin ... and ... peculiarly characteristic of the slave” (SBF, 208), so Lanier provides his own race-based canon of song: "I have selected out of the body of English poetry five battle-songs, written at intervals of three centuries apart. ... Surely no one can regard without interest this succession of manful songs, all moving in exactly the same verse-beat and carrying us on their rhythmic movement, by three-century leaps, through twelve centuries of English verse” (SEV, 137). Both Lanier and DuBois place their respective Sorrow Songs on opposite sides of a musically based color line. ${ }^{78}$ Included in DuBois’s list of “master songs” is “Swing Low, Sweet Chariot,” which appears in musical notation as an epigraph to chapter 12 of The Souls of Black Folk (see fig. 2). This is the same song that Dvořák gives to the flute in his symphony From the New World, but while Dvořák wants to present it as American national music, DuBois, we see, claims it as distinctively Negro — not of the New World but of the Old World (African, not European) that the slaves brought to America. ${ }^{79}$ Above this song, DuBois prints a passage from Tennyson. Tennyson had been the explicit object of Whitman’s complaint about poetry that is British 
instead of American, but Lanier had praised Tennyson for having "carried-on the ancient battlerhythmus of the fathers”; moreover, as we have seen, Lanier assimilated all poetry to music, even placing "the alphabet on exactly the same plane with the common European musical system of notation.” ${ }^{80}$ Thus Lanier (if not DuBois himself) would have viewed this epigraph from Tennyson as nothing more than musical notation for an Anglo-Saxon song. From Lanier's perspective, then, DuBois’s page presents us with two adjacent instances of sound notation; no words, only music. But they are not simply two songs; they are, according to Lanier and DuBois, an Anglo-Saxon song and a Negro song.

While DuBois may not have shared Lanier’s investment in reducing Tennyson’s poems to Anglo-Saxon sounds, he was deeply invested in the blackness of the Sorrow Songs: "We are that people whose subtle sense of song has given America its only American music,” DuBois wrote in “The Conservation of Races” (1897). ${ }^{81}$ But this is not “American music” in the Dvořák sense, for while Dvořák had envisioned a single music for a unified New World nation, DuBois asserts of "the Negro people" that "their destiny is not absorption by the white Americans" (“CR,” 23). Seeking to avoid such racial "self-obliteration,” DuBois imagines “200,000,000 black hearts beating in one glad song of jubilee” (“CR,” 24, 23). Race is conserved, then, through the racial identity inherent in these sounds, sounds that were, are, and ever shall be. $\frac{82}{\text { The }}$ question, then, is not whether the jubilee songs are intrinsically racial but whether the race they embody is one's own — whether they are "of me and of mine" - and whether one will choose to acknowledge them as such. On this point DuBois’s instruction is clear: “[I]t is our duty to conserve ... our spiritual ideals; as a race we must strive" toward "that broader humanity" — that cultural pluralism — “which freely recognizes differences in men, but sternly deprecates inequality in their opportunities of development” (“CR,” 25). Difference among races is 
something DuBois “freely recognizes" so long as its effect on cultural resources is not to restrict access to them (such as excluding John from the Wagner concert) but to regulate how people identify with them. If no one is socially barred from hearing these songs, some are racially barred from identifying with them and others are racially required—“it is our duty” (“CR,” 25)—-to view them as "of me and of mine."

DuBois opposed Booker T. Washington’s call for “separation” in “all things purely social,” but he doesn't eliminate the color line so much as displace it, transporting it from a social context to a literary one, making sounds_-and, by extension, the people whose sounds they are—seem “as separate as the fingers” of a hand. In 1876 Whitman heralds an American nation emerging from civil war to embark upon its “full Democratic career,” and in 1895 Dvořák proposes the musical forms on which such a "New World Nationality" will be based. Lanier and DuBois, however, subordinate American national identity to racial identity, and their respective commitments to Anglo-Saxon and Negro music together inscribe within literary form what would become "the problem of the Twentieth Century," the problem of the color line $(S B F, 1)$. 


\section{Notes}

1. In his discussion of the Centennial Cantata, Charles Hamm observes that "the idea was to have a 'Yankee' and a 'Rebel' combine talents, as a symbol of reconciliation between North and South" (Music in the New World [London: Norton, 1983], 325).

2. Sidney Lanier, “The Centennial Meditation of Columbia,” in Poems and Poem Outlines, ed. Charles R. Anderson, vol. 1 of The Centennial Edition of the Works of Sidney Lanier, ed. Anderson (Baltimore: Johns Hopkins Univ. Press, 1945), 61. Further references to this poem, hereafter called the Centennial Cantata, will be to this edition and will be cited parenthetically in the text as "CMC"; subsequent references to Poems and Poem Outlines will be cited parenthetically in the text as $P P O$.

3. Walt Whitman, "Preface 1876-Leaves of Grass and Two Rivulets," Leaves of Grass, ed. Sculley Bradley and Harold W. Boldgett (New York: Norton, 1973), 751, 746-47; further references to "Preface 1876" and to Whitman's poems will be to this edition and will be cited parenthetically in the text as $L G$.

4. See Exodus 3:14, where God reveals himself to Moses with a name that can be translated as either "I am what I am" or "I will be what I will be"; see also Revelation 1:8: "I am the Alpha and the Omega,' says the Lord God, who is and who was and who is to come, the Almighty" (The New Oxford Annotated Bible, New Revised Standard Version [1991]).

5. Lanier, “The Centennial Cantata,” in "The Science of English Verse” and Essays on Music, ed. Paull Franklin Baum, vol. 2 of The Centennial Edition of the Works of Sidney Lanier, ed. Charles R. Anderson (Baltimore: Johns Hopkins Univ. Press, 1945), 272-73. Further references to this essay will be to this volume and will be cited parenthetically in the text as "CC." Subsequent references to "The Science of English Verse" and Essays on Music will be cited parenthetically in the text as "SEV."

6. See Houston A. Baker Jr., Modernism and the Harlem Renaissance (Chicago: Univ. of Chicago Press, 1987), 57, 62; and Eric Sundquist, To Wake the Nations: Race in the Making of American Literature (Cambridge: Harvard Univ. Press, 1993), 529-30.

7. Thomas Jefferson, quoted in Stanley R. Hauer, “Thomas Jefferson and the Anglo-Saxon Language,” PMLA 98 (October 1983): 880. For further discussion of Jefferson’s AngloSaxonism, see Reginald Horsman, Race and Manifest Destiny (Cambridge: Harvard Univ. Press, 1981), 18-23; and Allen J. Frantzen, Desire for Origins (New Brunswick, N.J.: Rutgers Univ. Press, 1990), 203-7.

8. For discussions of the role played by Anglo-Saxon in accounts of Manifest Destiny, see Horsman, Race and Manifest Destiny, 1-6; and J. R. Hall, "Mid-Nineteenth-Century American Anglo-Saxonism: The Question of Language,” Anglo-Saxonism and the Construction of Social Identity, ed. Allen J. Frantzen and John D. Niles (Gainesville: Univ. Press of Florida, 1997), 134. 9. Arthur Mann, The One and the Many: Reflections on the American Identity (Chicago: Univ. of Chicago Press, 1979), 128.

10. Gregory A. VanHoosier-Carey, "Byrhtnoth in Dixie: The Emergence of Anglo-Saxon Studies in the Postbellum South," in Anglo-Saxonism and the Construction of Social Identity, ed. Frantzen and Niles, 165.

11. See VanHoosier-Carey, "Byrhtnoth in Dixie,” 161-63; and J. R. Hall, "Nineteenth-Century America and the Study of the Anglo-Saxon Language: An Introduction," in Preservation and Transmission of Anglo-Saxon Culture, ed. Paul E. Szarmach and Joel T. Rosenthal (Kalamazoo: Western Michigan Univ., 1997), 47-49. 
12. Lanier, Letter to Daniel C. Gilman, 22 October 1876, Letters 1874-1877, ed. Charles R. Anderson and Aubrey H. Starke, vol. 9 of The Centennial Edition of the Works of Sidney Lanier, ed. Charles R. Anderson (Baltimore: Johns Hopkins Univ. Press, 1945), 406.

13. Lanier, Letter to Daniel C. Gilman, 13 July 1879, Letters 1878-1881, ed. Charles R. Anderson and Aubrey H. Starke, vol. 10 of The Centennial Edition of the Works of Sidney Lanier, ed. Charles R. Anderson (Baltimore: Johns Hopkins Univ. Press, 1945), 130.

14. On the activities of Gilman, Lanier, and Whitney at Johns Hopkins, see Hugh Hawkins, Pioneer: A History of the Johns Hopkins University, 1874-1889 (Ithaca, N.Y.: Cornell Univ. Press, 1960).

15. William Dwight Whitney, The Life and Growth of Language (New York: Dover, 1979), 145, 24; hereafter this source will be cited parenthetically in the text as $L G L$. Whitney's position was later invoked by Ferdinand de Saussure: "To emphasize the fact that language is a genuine institution, Whitney quite justly insisted upon the arbitrary nature of signs; and by so doing, he placed linguistics on its true axis" (Course in General Linguistics, trans. Wade Baskin [New York: Philosophical Library, 1959], 76).

16. Kenneth Cmiel, Democratic Eloquence: The Fight over Popular Speech in NineteenthCentury America (New York: William Morrow, 1990), 156. For a useful discussion of the contemporary debate between scientific philologists like Whitney and verbal critics like Richard Grant White, see chaps. 4-6, especially 153-56.

17. Lanier, "From Bacon to Beethoven," in "SEV," 276. Further references to this essay will be to this volume and will be cited parenthetically in the text as "BB."

18. While Lanier's early public defense of his Centennial Cantata pairs "conventionally significant words" with "unconventionally significant tones," taking the "general idea” of the words to be "reproducible . . by orchestral effects” (“BB,” 267, 271), he later explicitly distances himself from this central commitment of "programme-music" (see "The Physics of Music," in "SEV," 252; and “BB," 278-81).

19. Lanier, quoted in introduction to "SEV," xiii.

20. See Lanier, “CC,” 268; and “Appendix,” “SEV,” 338.

21. Richard Wagner, Beethoven; With a Supplement from the Philosophical Works of Arthur Schopenhauer, trans. Ed Dannreuther (London: New Temple Press, 1870), 70; further references to this source will be cited parenthetically in the text as $B$.

22. A slightly longer passage helps clarify Wagner's views: "Music loses nothing of its character when very different words are set to it; and this fact proves that the relation of music to the art of poetry is an entirely illusory one; for it holds true that when music is heard with singing added thereto, it is not the poetical thought . . . that is grasped by the auditor; but, at best, only that element of it which, to the musician, seemed suitable for the music, and which his mind transmuted into music" $(B, 74)$.

23. For useful discussions of Wagner's changing views on opera, with particular reference to the influence of Schopenhauer, see Carl Dahlhaus, Between Romanticism and Modernism: Four Studies in the Music of the Later Nineteenth Century, trans. Mary Whittall (Berkeley and Los Angeles: Univ. of California Press, 1980), 33-39; and Bryan Magee, The Philosophy of Schopenhauer (New York: Oxford Univ. Press, 1997), 350-402.

24. Lanier, The Science of English Verse, in "SEV," 42. Further references to this source will be to this volume and will be cited parenthetically in the text as $S E V$. 
25. Whitney goes on to assert, "The very earliest dialects are as exclusively conventional as the latest; the savage has no keener sense of etymological connection than the man of higher civilization" (LGL, 297; see also 19).

26. Lanier, "Lecture XI: The Sonnet-Makers from Surrey to Shakspere,” Shakspere and His

Forerunners: The Peabody Lectures, in Shakspere and His Forerunners, ed. Kemp Malone, vol. 3 of The Centennial Edition of the Works of Sidney Lanier, ed. Charles R. Anderson (Baltimore: Johns Hopkins Univ. Press, 1945), 87.

27. Here I emphasize Lanier's notion of Anglo-Saxon self-identity (that is, the language's relation to itself over time) rather than his notion of Anglo-Saxon superiority (the language's relation to other languages at a given moment), but the latter notion is also present in Lanier's thinking. For a discussion that emphasizes this aspect of Lanier's work, see VanHoosier-Carey, "Byrhtnoth in Dixie," 169-70.

28. Lanier, "Lecture I," in Shakspere and His Forerunners, ed. Malone, 7.

29. On the remote grammar of Anglo-Saxon, see Lanier, "Lecture VII: Beowulf and Midsummer Night's Dream," Shakspere and His Forerunners, ed. Malone, 24; on its remote pronunciation, see "Lecture XVI: Pronunciation of Shakspere's Time," Shakspere and His Forerunners, 173; and on its remote semantics, see "Lecture X: The Wife in Middle English Poetry," Shakspere and His Forerunners, 83. For Whitney’s similar statements about the dramatic changes in English, see $L G L, 32-44$.

30. Lanier, “Lecture VII,” in Shakspere and His Forerunners, ed. Malone, 23.

31. See Hauer, "Thomas Jefferson and the Anglo-Saxon Language," 882, 880.

32. See Lanier's focus on sound in "Introduction to the Boy's Froissart" in "The English Novel" and Essays on Literature, ed. Clarence Gohdes and Kemp Malone, vol. 4 of The Centennial Edition of the Works of Sidney Lanier, ed. Charles R. Anderson (Baltimore, Johns Hopkins Univ. Press, 1945), 353; and "Introduction to the Boy’s King Arthur” ("The English Novel” and Essays on Literature, 361-64).

33. While the word "sound" here refers specifically to rhythm, rhythm is just one aspect of Lanier's complex account of sound, an account that addresses questions of duration, intensity, pitch, and tone color (see $S E V, 23-29$ ). I focus on rhythm because Lanier singles it out to do the work of racial continuity.

34. Lanier offers the following account of why the word "English" appears at all in the title of his The Science of English Verse: "The science of verse, then observes and classifies all the phenomena of rhythm, of tune, and of tone-color, so far as they can be exhibited to the ear directly by spoken words,- - or to the ear, through the eye, by written or printed signs of spoken words,- - or to the mind by the conception of spoken words; and, The science of English verse observes and classifies these phenomena so far as they can be indicated through the medium of spoken English words” (SEV, 48; Lanier's emphasis). Here English is transformed from an institution of arbitrary signs into a "medium” for sound notation. But if, as we have seen, English is sufficient but not necessary to record the sounds of poems, then calling this the science of English verse seems mistaken: the sounds in question may coincide with the sounds in English, but without meanings attached they have ceased to be English and belong instead to the (in his view) extralinguistic domain of music. To continue to describe these sounds as Anglo-Saxon is to imagine this Anglo-Saxonness residing within them at a level deeper than conventional meaning.

35. For a thorough summary of the critical reception of Lanier's theories up to 1945, see introduction to "SEV," xxx-xliv. For more recent treatments, see Jane S. Gabin, A Living 
Minstrelsy: The Poetry and Music of Sidney Lanier (Macon, Ga.: Mercer Univ. Press, 1985), 153-56; and Harvey Gross and Robert McDowell, Sound and Form in Modern Poetry, 2d ed. (Ann Arbor: Univ. of Michigan Press, 1996), 5.

36. The concern with musical sound among nineteenth-century writers involved not only poems but also, as Caroline Levander observes, "the tone of the female voice" (Voices of the Nation: Women and Public Speech in Nineteenth-Century Literature and Culture [New York: Cambridge Univ. Press, 1998], 14). The writers Levander addresses "increasingly identified the nation's integrity with the voices of American women" (9) and thus, in "attempt[ing] to ensure the exclusive tonality of women's speech" (21), sought to perpetuate not racial but national identity. Consolidating this national identity involved preserving the "purity" of women's voices rather than perpetuating the rhythm of poems, and the vehicle of the former was "women's relegation to the private sphere" $(16,22)$ while the vehicle of the latter was the attribution of racial form to poetic texts.

37. See David S. Reynolds, Walt Whitman's America: A Cultural Biography (New York: Knopf, 1995), 514-15.

38. Whitman, quoted in Robert D. Faner, preface to Whitman \& Opera (Philadelphia: Univ. of Pennsylvania Press, 1951), v.

39. This essay was later retitled "Poetry To-day in America—Shakspere-The Future" (see Whitman, Prose Works 1892, ed. Floyd Stovall, 2 vols. [New York: New York Univ. Press, 1964], 2:474). Subsequent references to this essay and to others in Prose Works will be cited parenthetically in the text as $P W$.

40. Whitman elaborates on this point in his "Slang in America" (1885) (in PW, 2:572-77).

Jonathan Arac usefully observes a problem that, contrary to Whitman's own aims, often arises as critics discuss Whitman's celebration of nonstandard usage: “[H]aving been used to define one set of bounds (America versus the Old World), vernacular becomes a means for drawing further bounds within the United States, as to what will count as authentically 'American'” "Whitman and Problems of the Vernacular," in Breaking Bounds: Whitman and American Cultural Studies, ed. Betsy Erkkila and Jay Grossman [New York: Oxford Univ. Press, 1996], 48).

41. Lanier, "Lecture III," "English Novel" and Essays on Literature, ed. Gohdes and Malone, 50 .

42. Lanier, "Lecture II," "English Novel” and Essays on Literature, ed. Gohdes and Malone, 27, 50; further references to this lecture will be to this volume and will be cited parenthetically in the text as "LII."

43. For his part, Whitman accused Lanier of all too strong an immersion in melody and sound: "Study Lanier's choice of words ... , [which] are too often fit rather for sound than for sense.... $[\mathrm{H}] \mathrm{is}$ over-tuning of the ear, this extreme deference paid to oral nicety, reduced the majesty, the solid worth, of his rhythms" (quoted in Aubrey Starke, "Lanier's Appreciation of Whitman," The American Scholar 2 [October 1933]: 408).

44. Many subsequent critics follow Lanier in locating Whitman's poetics in an ongoing AngloSaxon tradition. For early versions of this view, see Sculley Bradley, "The Fundamental Metrical Principle in Whitman's Poetry,” American Literature 10 (January 1939): 437-59; and John E. Bernbrock, "Walt Whitman and 'Anglo-Saxonism”” (Ph.D. diss., Univ. of North Carolina, 1961), 159-88. In a more recent version of this approach, Dana Phillips laments that Whitman "merely refers" to "the sounds of different cultures from all around the world" instead of providing a "degree of onomatopoeia, or actual physical likeness to the sounds." Having been filtered through Whitman as "medium," the sounds of other cultures are thereby subordinated to 
the sounds of Whitman's speaker who-as Lanier would say—speaks in racial sounds, the sounds of a "White Father" ("Nineteenth-Century Racial Thought and Whitman's 'Democratic Ethnology of the Future,"” Nineteenth-Century Literature 49 [December 1994]: 292, 293 n. 4). The difference between Phillips and Lanier, then, is that while Lanier considers the racial identity intrinsic to Whitman's sounds a good thing (since Anglo-Saxon rhythm thereby perpetuates itself, even in a speaker explicitly resistant to the Old World), Phillips finds it objectionable, since Whitman's essentially "White" sound excludes other sounds and the racial identities embodied in them. Martha C. Nussbaum defends Whitman's ambition to speak for “excluded people," but in her account Whitman succeeds not because of his poems' formal features but because his "commitment both to narrative and to the concrete depiction of different ways of life brings him into close contact with the novel" (Poetic Justice: The Literary

Imagination and Public Life [Boston: Beacon Press, 1995], 119, 7).

45. Lanier, "Lecture XII: The Sonnet-Makers,” in Shakspere and His Forerunners, ed. Malone, 114.

46. Lanier, “Lecture VII,” in Shakspere and His Forerunners, ed. Malone, 33. This emphasis on Scottish sounds is apparent in the concluding words of Lanier's The Science of English Verse: "King James has summed up the whole matter in his homely Scotch words: 'Zour eare maun be the onely iudge, as of all the other parts of Flowing,' (that is, of rhythmic movement) 'the verie twichestane quhairof is musique"” (“SEV," 244).

47. Lanier fought for the Confederacy as "a full-blooded secessionist” (introduction to "TigerLilies" and Southern Prose, ed. Garland Greever, vol. 5 of The Centennial Edition of the Works of Sidney Lanier, ed. Charles R. Anderson [Baltimore: Johns Hopkins Univ. Press, 1945], liv). Although Lanier ultimately accepted the North's victory, his poems of the period immediately following the war frequently criticize the policies of Reconstruction; see "To Our Hills" (1867; $P P O, 167)$; "Laughter in the Senate” (1868; PPO, 14); and "Steel in Soft Hands" (1868; PPO, 169). See also Lanier, "Furlow College Address” (1869; “Tiger-Lilies” and Southern Prose, ed. Greever, 258); "Confederate Memorial Address” (1870; “Tiger-Lilies” and Southern Prose, 269); "Retrospects and Prospects” (1871; “Tiger-Lilies” and Southern Prose, 303); and Aubrey Harrison Starke, Sidney Lanier: A Biographical and Critical Study (Chapel Hill: Univ. of North Carolina Press, 1933), 112-13.

48. According to Eric Foner, "This measure ... made it illegal for places of public accommodation and entertainment to make any distinction between black and white patrons, and outlawed racial discrimination in public schools, jury selection, churches, cemeteries, and transportation” (Reconstruction: America's Unfinished Revolution, 1863-1877 [New York: Harper \& Row, 1988], 532-33). Subsequent references to this source will be cited parenthetically in the text as $R$.

49. Joel Williamson describes this change as “a beginning of 'white soul.' In the end,"

Williamson continues, "the essence of the old order, the sense of Southernness and whiteness as qualities uniquely valuable, was saved. ... The term that they applied to regaining control of their states was as fully laden with meaning as the Christian view of the rebirth of the spirit. They called it 'Redemption'” (A Rage for Order: Black/White Relations in the American South since Emancipation [New York: Oxford Univ. Press, 1986], 39).

50. Ohio governor Rutherford B. Hayes, who would ascend to the presidency through the compromise that ended Reconstruction, wrote to a Southern friend, “'The let alone policy' seems now to be the true course; at any rate nothing but good will now exists towards you" (quoted in $R$, 558; see also, 567). 
51. Nation, 5 April 1877; quoted in $R, 582$.

52. Starke, Sidney Lanier, 186.

53. W. E .B. DuBois, The Souls of Black Folk (New York: Penguin, 1989), 205. Subsequent references to this source will be to this edition and will be cited parenthetically in the text as SBF.

54. J. B. T. Marsh, The Story of the Jubilee Singers: With Their Songs. With Supplement Containing an Account of Their Six Years' Tour around the World, and Many New Songs, by F. J. Loudin, new edition (Cleveland, Ohio: Cleveland Printing \& Publishing, 1892), 17, 18; hereafter, this source will be cited parenthetically in the text as SJS. On the array of contemporary editions of this text, see Dena J. Epstein, “The Story of the Jubilee Singers: An Introduction to its Bibliographic History," New Perspectives on Music: Essays in Honor of Eileen Southern, ed. Josephine Wright (Warren, Michigan: Harmonie Park Press, 1992), 151-62. 55. John Lovell Jr., Black Song: The Forge and the Flame; The Story of How the Afro-American Spiritual Was Hammered Out (New York: Macmillan, 1972), 406.

56. Their successes included gaining an audience with the queen, earning an invitation to Gladstone's residence, and prompting the following comment from Lord Shaftsbury: “I don't want them to become white, but I have a strong disposition myself to become black. If I thought color . . brought with it their truth, piety, and talent, I would willingly exchange my complexion to-morrow" (SJS, 50, 84, 80).

57. For discussion of the religious orientation of the Jubilee Singers, see G. D. Pike, The Jubilee Singers, and Their Campaign for Twenty Thousand Dollars (Boston: Lee and Shepard, 1873), 924; Louis D. Silveri, “The Singing Tours of the Fisk Jubilee Singers: 1871-74,” in Feel the Spirit: Studies in Nineteenth-Century Afro-American Music, ed. George R. Keck and Sherrill V. Martin (New York: Greenwood, 1988), 106-9; and Andrew Ward, Dark Midnight When I Rise: The Story of the Jubilee Singers Who Introduced the World to the Music of Black America (New York: Farrar, Straus and Giroux, 2000), 100-106.

58. Lovell, Black Song, 415.

59. Whitman, “Lately, I have wonder'd whether the last meaning of this cluster of thirty-eight States is not only practical fraternity among themselves . . . but for fraternity over the whole globe” (PW, 2:484).

60. Antonín Dvořák, “Letter to the Editor,” New York Herald, 28 May 1893; reprinted in Dvořák in America: 1882-1895, ed. John C. Tibbetts (Portland, Oregon: Amadeus Press, 1993), 359; subsequent references to Dvořák in America will appear parenthetically in the text as DA. 61. Dvořák, “The Real Value of Negro Melodies,” New York Herald, 21 May 1893; reprinted in DA, 356-57.

62. As John Higham notes, this shift in immigration patterns altered the reception new immigrants received: “No longer scorned simply for 'mere habits of life,' each of the major groups from southern and eastern Europe stood forth as a challenge to the nation, either endangering American institutions by unruly behavior or threatening through avarice to possess them” (Strangers in the Land [Westport, Conn.: Greenwood, 1963], 94). This perceived challenge led some to respond with plans for legal restriction and others with programs of aggressive assimilation (97-105, 74-75).

63. Dvořák, “Music in America,” Harper's, February 1895; reprinted in DA, 376.

64. See Dvořák's claim in “The Real Value of Negro Melodies” that "Many of the negro melodies - most of them, I believe-are the creations of negroes born and reared in America. That is the peculiar aspect of the problem. The negro does not produce music of that kind 
elsewhere. I have heard black singers in Hayti for hours and, as a rule, their songs are not unlike the monotonous and crude chantings of the Sioux tribes. It is so also in Africa. But the negro in America utters a new note, full of sweetness and as characteristic as any music of any country" (DA, 357-58).

65. Dvořák, "Real Value of Negro Melodies," in DA, 355-56.

66. Dvoř́k, "Music in America," in DA, 377.

67. Dvorák, "Hear the 'Old Folks at Home,'” New York Herald, 23 January 1894; quoted in DA, 366.

68. Dvořák, "For National Music," Chicago Tribune, 13 August 1893; reprinted in DA, 362.

69. Henry Burleigh, quoted in Thomas L. Riis, "Dvořák and his Black Students," Rethinking Dvořák: Views from Five Countries (New York: Oxford Univ. Press, 1996), 266. For a skeptical reading of Dvořák's nationalism, see Michael Beckerman, “The Master’s Little Joke: Antonín Dvořák and the Mask of Nation," in Dvořák and His World, ed. Michael Beckerman (Princeton, N.J.: Princeton Univ. Press, 1993), 134-54.

70. Theodore F. Seward, "Preface to the Music," SJS, 156.

71. Quoted in "Dvořák on His New Work,"New York Herald, 15 December 1893; reprinted in DA, 363.

72. "Dvořák seems to be describing familiar pentatonic and Dorian scales" (Riis, "Dvořák and His Black Students,” 267).

73. Michael Beckerman responds to this question by arguing, "Composers who wish to employ exotic material are often in search of what I call 'multicultural puns,' that is, musical figures or devices that are common to at least two cultures”; Dvořák, then, is choosing sounds that belong both to his own culture and to U.S. culture ("Henry Krehbiel, Antonín Dvořák, and the Symphony 'From the New World,"” Notes 49 [December 1992]: 462). But if the example of the pun demonstrates how multiple meanings (signifieds) can be associated with the same sound (signifier), this linguistic analogy relegates cultural difference to signifieds and thus begs the question of how multiple cultures can be embodied in the same nonlinguistic, or musical, sound. 74. James Huneker, “Dvořák's New Symphony: The Second Philharmonic Concert,” Musical Courier, 20 December 1893; reprinted in Dvorák and His World, ed. Beckerman, 163; see also 160.

75. Booker T. Washington, "The Atlanta Exposition Address," in Up from Slavery, in Three Negro Classics (New York: Avon Books, 1965), 148.

76. For a similar account, which likewise reads Wagner's music as "white," see Sundquist, To Wake the Nations, 523. For an alternative reading, which interprets Wagner's music in this scene as symbolizing DuBois's "desire for a race-blind love," see Russell A. Berman, "Du Bois and Wagner: Race Nation, and Culture between the United States and Germany," German Quarterly 70 (spring 1997): 130.

77. In other words, just as Lanier had opposed the Civil Rights Bill and sought instead to consolidate one people-Anglo-Saxons—out of Northern and Southern whites, so DuBois opposes both the Redeemers' oppressions and Booker T. Washington's concessions, seeking instead to consolidate one people-Negroes—out of Northern and Southern blacks (SBF, 47). Just as Lanier tried to consolidate Anglo-Saxon people by asserting the race inherent in poetic rhythm, so DuBois consolidates a Negro people by asserting the race inherent in the Sorrow Songs. For a useful critical discussion of DuBois's effort to achieve racial unity and that effort's problematic legacy, see Kenneth Warren, "Delimiting America: The Legacy of Du Bois," American Literary History 1 (spring 1989): 172-89. 
78. Sundquist notes that DuBois's analysis of the Sorrow Songs "reduces language to sound" (To Wake the Nations, 529), and Sundquist follows DuBois's lead in racializing that sound when he argues that since the Sorrow Songs enter "the domain of sheer sound," they inhabit "the extremity of African American cultural expression, the domain where the cry fades into an articulacy reaching beyond European American apprehension” (531). My analysis suggests, however, that in the writers of this period, the domain of sheer sound is providing a new opportunity to assert the existence of race, whether Anglo-Saxon or Negro. Although Sundquist denies that his own account of DuBois is "a brief for Afrocentrism" (15), he is generally more appreciative than critical as he repeatedly highlights DuBois's assertions of sound as intrinsically African (472, 511, 525-39). Houston Baker shares Sundquist's commitment to identifying a specifically African American sound in The Souls of Black Folk (Modernism and the Harlem Renaissance, 56-68). Shamoon Zamir likewise takes race to be "embodied" in the spirituals (Dark Voices: W. E. B. Du Bois and American Thought, 1888-1903 [Chicago: Univ. of Chicago Press, 1995], 170, 171, 172, 175), but he sees the spirituals less as a vehicle for consolidating racial identity ("an essentialized idea of communitas" [181]) than as a vehicle for DuBois's own autobiographical narrative of "self-transformation” (184). Paul Gilroy recognizes that DuBois installs "slave music . . . in its special position of privileged signifier of black authenticity," but he goes on to "resist . . . the idea that an untouched, pristine Africanity resides inside these forms” (The Black Atlantic: Modernity and Double Consciousness [Cambridge: Harvard Univ. Press, 1993], 91, 101). For a similar statement of resistance, see Ronald M. Radano, "Soul Texts and the Blackness of Folk,” Modernism/Modernity 2 (January 1995): 84.

79. This melody undoubtedly came to the United States from Africa (see Sundquist, To Wake the Nations, 519-20), but the question of its provenance is not the same as the question of its essence, and it is this latter question - the question of what people, if any, the song embodiesthat I am addressing here.

80. Lanier, “Lecture XVI: Pronunciation of Shakspere’s Time,” Shakspere and His Forerunners, ed. Malone, 169.

81. DuBois, “The Conservation of Races,” in W. E. B. Du Bois: A Reader, ed. David Levering Lewis (New York: Henry Holt, 1955), 25; further references to this source will be to this edition and will be cited parenthetically in the text as "CR."

82. Anthony Appiah and Ross Posnock have shown that in his later career DuBois sought to achieve something Lanier never imagined: abandoning race as a central category of social organization. While Appiah argues that this effort failed and Posnock counters that it succeeded, they agree that DuBois's early writings set out the commitment to race from which he would later seek to retreat. It is these early writings and their commitment to "the unifying ideal of Race” that I am addressing here $(S B F, 11)$; see Anthony Appiah, "The Uncompleted Argument: Du Bois and the Illusion of Race,” in "Race,” Writing, and Difference, ed. Henry Louis Gates Jr. (Chicago: Univ. of Chicago Press, 1985), 21-37; and Ross Posnock, Color \& Culture: Black Writers and the Making of the Modern Intellectual (Cambridge: Harvard Univ. Press, 1998), 8889, 18-19. 